\title{
Nodulation, morphological and yielding components of chickpea as influenced by tillage practices under varying potassium levels
}

\author{
Abrar Ahmad ${ }^{1}$, Inamullah ${ }^{1}$, Haq Nawaz ${ }^{1 *}$, Muhammad Mehran Anjum ${ }^{1}$, \\ Nawab Ali ${ }^{1}$, Muhammad Zuhair ${ }^{1}$, Muhammad Kefayatullah ${ }^{2}$, \\ Muhammad Farhan Khan Pasha ${ }^{3}$, Mukaram Shah ${ }^{3}$, Younis Jan ${ }^{1}$ and \\ Maaz Khan ${ }^{1}$ \\ 1. Department of Agronomy, the University of Agriculture Peshawar-Pakistan \\ 2. Department of Food Science and Technology, the University of Agriculture Peshawar-Pakistan \\ 3. Agriculture Research Institute Tarnab Peshawar-Pakistan \\ *Corresponding author's email: abraruap@gmail.com \\ Citation \\ Abrar Ahmad, Inamullah, Haq Nawaz, Muhammad Mehran Anjum, Nawab Ali, Muhammad Zuhair, Muhammad \\ Kefayatullah, Muhammad Farhan Khan Pasha, Mukaram Shah, Younis Jan and Maaz Khan. Nodulation, \\ morphological and yielding components of chickpea as influenced by tillage practices under varying potassium \\ levels. Pure and Applied Biology. Vol. 8, Issue 2, pp1100-1110. http://dx.doi.org/10.19045/bspab.2019.80052 \\ \begin{tabular}{llll}
\hline Received: 26/01/2019 & Revised: 21/03/2019 & Accepted: 26/03/2019 & Online First: 01/04/2019
\end{tabular}
}

\section{Abstract}

Field experiment was conducted to evaluate the effect of tillage practices and potassium levels on growth, yield and yield components of chickpea, at Agronomy Research Farm, The University of Agriculture Peshawar Pakistan, in winter 2015-16. The experimental results exhibited that among tillage practices deep tillage significantly affected weed density $\left(438 \mathrm{~m}^{-2}\right)$, weeds dry weight $\left(6.4 \mathrm{~g} \mathrm{~m}^{-2}\right)$, weeds fresh weight $(13.5$ $\left.\mathrm{g} \mathrm{m}^{-2}\right)$, nodules weight $\left(1.15 \mathrm{~g} \mathrm{plant}^{-1}\right)$, plant height $(83.3 \mathrm{~cm})$, number of branches plant ${ }^{-1}(11)$, days to maturity (196), grain yield (1447 kg ha-1), biological yield (4155 kg ha-1) and harvest index (37.5\%), however days to emergence, emergence $\mathrm{m}^{-2}$, days to $50 \%$ flowering, number of nodules, number of pods plant $^{-1}$, grains pod ${ }^{-1}$, pods $\mathrm{m}^{-2}$ were non-significantly affected by tillage practice. The minimum grain yield and other yield related characters were observed in shallow tillage practice. Potassium had significant impact on number of nodules $\left(16.0\right.$ plant $\left.^{-1}\right)$, nodules weight $\left(1.10 \mathrm{~g} \mathrm{plant}^{-1}\right)$, plant height $(81.3 \mathrm{~cm})$, number of pods plant ${ }^{-1}$ (33.5), pods $\mathrm{m}^{-2}$ (837), days to maturity (196), 100 grain weight (25.3 g), grain yield (1483 $\left.\mathrm{kg} \mathrm{ha}^{-1}\right)$, biological yield (4244 $\mathrm{kg} \mathrm{ha}^{-1}$ ) and harvest index (37.6\%), whereas days to emergence, emergence $\mathrm{m}^{-2}$, weed density, weeds dry weight, weeds fresh weight, number of branches plant ${ }^{-1}$, days to $50 \%$ flowering were not significantly affected. The interaction between tillage practices and potassium levels was significant for only $50 \%$ flowering while non-significant for the rest of parameters. Thus it is concluded from the experiment that deep tillage performed better as compared with shallow and medium deep tillage practices in terms of yield and yield components. Potassium application at the rate of $60 \mathrm{~kg} \mathrm{ha}^{-1} \mathrm{improved}$ growth and productivity in Peshawar region.

Keywords: Chickpea; Grain yield; Nodules; Potassium; Yield 


\section{Introduction}

Chickpea (Cicer arietinum L.) is the pulse crop produced in rain-fed areas, belonging to the family Fabaceae. It is an important cool season, self-pollinated annual crop, however, cross pollinated is rare; only $0-1 \%$ is reported [1] that completes their life cycle in 90-180 days and their leaves turn brown/yellow during maturity, and depends on different meteorological conditions around the globe [2]. There are various factors that contributed to its low yielding in Pakistan, but the imbalance use of fertilizers is of prime importance. Among fertilizers, Potassium play major role in water economy and growth of crop which effects on uptake of water, root growth, turgor maintenance, stomatal and transpiration regulation [3]. Most soils have high amount of total potassium but a very less amount is available to uptake by the plants. Potassium got the prime important nutrient of the crops. Potassium plays major contribution to stomatal movement, osmotic adjustment and restriction of uptake of $\mathrm{Na}^{+}$ under saline condition [4]. Besides the useful character of the fertilizers, it also promotes other agricultural practices [5-8]. Out of the total potassium in soil, slowly available potassium accounts for 1-2 \% while 90-98 \% of the total potassium in soil is not available readily to the plants [9].

Tillage affects many soil properties including physical and chemical properties such as soil porosity, soil bulk density, soil nitrate concentration, contents of carbon, soil aeration, soil life and water contents of soil [10-12], as a result, it effects $\mathrm{N}_{2} \mathrm{O}$ emissions and denitrification that losses nitrogen from the soil $[10,13]$.

Conservation tillage practices is recommended to adapt in the soil of arid and semiarid lands where there is low rainfall i.e. 200-400 $\mathrm{mm}$ [14]. Literature on tillage practices reported that conventional and deep tillage can improve soil aeration [15] porosity of the soil and also helps in improving the life of microbes and conservation of soil nutrients and moisture for crop plants [16]. Emergence of seedlings and yield of the crops are the factors which are influences by the soil moisture, bulk density and compaction degree of the soil [17].

Keeping in view the importance of tillage practices and potassium fertilizer, the present investigation is planned to determine the effect of different tillage systems and potassium levels on yield and yield components of chickpea.

\section{Materials and methods}

\section{Experimental details}

The experiment was laid out in randomized complete block design with split plot arrangement having four replications. A subplot size $2.4 \mathrm{~m}$ x $5 \mathrm{~m}$ was used, each plot was comprised of 6 rows with $40 \mathrm{~cm}$ row to row distance and $10 \mathrm{~cm}$ plant to plant distance. Chickpea variety Karak-3 was sown at the rate of $60 \mathrm{~kg} \mathrm{ha}{ }^{-1}$. Three tillage practices (shallow, medium deep and deep) were assigned to main plots and 5 levels of potassium $\left(\mathrm{K}_{0}=0, \mathrm{~K}_{1}=20, \mathrm{~K}_{2}=40, \mathrm{~K}_{3}=60\right.$, $\mathrm{K}_{4}=80 \mathrm{~kg} \mathrm{ha}^{-1}$ ) were allotted to sub plot. The tillage practices were carried out in such a way that first those plots were ploughed with the help of chisel plough where deep tillage were assigned and secondly those plots were ploughed with mould board plough where medium deep tillage were assigned and after that the whole field was thoroughly ploughed with cultivator followed by planking and a fine seed bed was prepared. Nitrogen at the rate of $40 \mathrm{~kg} \mathrm{ha}^{-1}$ in the form of Urea was applied at sowing time. Phosphorus at the rate of $70 \mathrm{~kg} \mathrm{ha}^{-1}$ in the form of DAP (Diammonium phosphate) was applied at sowing time. Source for potassium was MOP (Muriate of potash).

\section{Statistical analysis}

Statistical analysis of data was carried out by using the procedure suitable for randomized complete block (RCB) design with the split plot arrangement. Means of each category 
was compared by using least significant difference (LSD) test at 5\% level of probability when $\mathrm{F}$ values are significant [18].

\section{Results and discussion}

Data regarding days to emergence was nonsignificantly influenced by tillage practices and potassium levels on chickpea (Table 1). The interaction between tillage and potassium ( $\mathrm{T} \times \mathrm{K}$ ) was also non-significant. Mean values of the data revealed that the effect of all three types of tillage and potassium was found non-significant. It might be credited to the chickpea grain have adequate reserve food in the endospermic region. So the days to emergence of chickpea grain is generally interrelated with endogenous grain reserve. The outer sources have negligible effect on emergence these lines are in similarity with [19]. The uniform days to emergence might be due to the practice of tillage it makes the soil pulverize, aerated and helps in leaching of salts from the surface of soil to the deeper layer of soil due to increase in infiltration rate which makes the environment good for emergence. Similar consequences were exhibited by [20] who stated that there is no significant effect of tillage management or any other inorganic fertilizer on days to emergence.

Data on emergence $\mathrm{m}^{-2}$ of chickpea are shown in (Table 1). Statistical analysis of the data indicated that emergence $\mathrm{m}^{-2}$ was nonsignificantly affected by tillage practices and potassium levels. The effect of different tillage practices shows similar results in terms of emergence $\mathrm{m}^{-2}$. Those plots which are fertilized with different potassium levels have statistically similar results in term of emergence $^{-2}$. The interaction between tillage and potassium ( $\mathrm{T} \times \mathrm{K}$ ) was also found nonsignificant. This may be due to no role of potassium on emergence $\mathrm{m}^{-2}$ as it is wholly solely biochemical processes which don't need potassium fertilizer and all tillage practices make the soil upper surface good for emergence ${ }^{-2}$. Tillage practice improved soil aggregates structure and makes the seedling withdrawal process easy from soil surface, therefore there is difference between tillage practice in terms of emergence ${ }^{-2}$, seedling uniformity and seedling vigor but statistically comparable with other tillage practice. These results are in conformity with [21] who reported non-significant effect of tillage practices on emergence $\mathrm{m}^{-2}$.

Data on weed density of chickpea are shown in (Table 1). Statistical analysis of the data indicated that weed density was significantly affected by tillage practices, whereas, the effect of potassium was found nonsignificant. The data shows that interactive effect of tillage and potassium ( $\mathrm{T} \times \mathrm{K}$ ) was non-significant. Lower number of weeds were noted in plots treated with deep tillage apparatus $\left(431.4 \mathrm{~m}^{-2}, 60\right.$ days, $453.9 \mathrm{~m}^{-2} 80$ days) followed by medium deep $\left(482.1 \mathrm{~m}^{-2}\right.$, 60 days, $499.2 \mathrm{~m}^{-2}, 80$ days) and higher weed density was observed in plots treated with shallow tillage apparatus $\left(493.4 \mathrm{~m}^{-2} 60\right.$ days, $509.9 \mathrm{~m}^{-2}, 80$ days). Weed density had not significantly affected by potassium levels. Due to deep tillage the roots of many perennial weeds species emanates to the ground, due do sunlight they lose their rejuvenation and the seed bank of weeds is also buried deep down and destroyed. According to [22] conventional tillage suppress the weed infestation as compared to minimum and zero tillage by preventing their growth by burying them deep enough in soil to prevent their emergence, disassembling and uprooting the weeds, or by changing the physical and chemical environment of soil which alters the germination and life cycle process of weeds and by moving their seed bank both vertically and horizontally. [23, 24]. Different studies showed that the growth of most black nightshade (Solanum nigrum L.) weeds can be controlled effectively by deep tillage practices because they emerge in great number only when the tillage is done to 
top 1 inch of the soil (shallow tillage) [25] One research personnel depicted that reduced tillage practice resulted in an increased population of annual morning glory in cotton [26].

The perusal of data in (Table 1) expose that main plot effect, tillage practice was significant at $0.05 \%$ level of probability. More branches (11) were attained by deep tillage practice which is significantly different from shallow tillage and medium deep tillage practice (10.2 and 9.8 respectively). The data stated that effect of potassium was non-significant. The interactive effect of tillage practices and potassium levels ( $\mathrm{T} \times \mathrm{K}$ ) was found nonsignificant. one of the prime parameters in term of photosynthates production, if crop canopy is more, more will be the photosynthetic material synthesized and eventually the crop plant will nourish well and will bear more pods. Number of branches was significantly affected by tillage practice. The data showed that number of branches plant $^{-1}$ increase significantly with the increase in depth of tillage equipment. Deep tillage produces more number of branches per plant (11) while less number of branches was produce by shallow tillage (9). Whereas potassium and the interaction of $(\mathrm{T} \times \mathrm{K})$ was non-significant. Report stated that improvement such as increased number of branching could possibly be because of improved NPK utilization efficiency in the presence of deep tillage practice. Because these primary elements have been found to show complementary role for each other. Same remarks were also shown by [27].

Data concerning days to $50 \%$ flowering was non-significantly affected by tillage practices and potassium levels which is shown in (Table 1). Less number of days to $50 \%$ flowering was recorded in those main plots where shallow tillage practice is done however medium deep and deep tillage practice taken more days to flowering but they are non-significant among themselves. Data of mean values reported that those plots where $80 \mathrm{~kg} \mathrm{ha}^{-1}$ potassium was applied produce postponement in flowering as compared to all those plots where less potassium was applied while delay in flowering was shown in control plots. The interaction between $\mathrm{T} \times \mathrm{K}$ was also significant. More number of days to $50 \%$ flowering was taken by the deep tillage with the higher level of potassium which is $80 \mathrm{~kg}$ $\mathrm{ha}^{-1}$ (112 days) while less number of days was taken by the control plots where shallow tillage practice was done. The probable reason for this might be the depth in tillage when increases the soil becomes porous the root movement becomes easy which leads to increase growth of the crop so when vegetative growth increases the flowering delays. So plough depth delays the days to 50 $\%$ flowering. The flowering is significantly affected by potassium levels as the potassium rate increases delay in days to $50 \%$ flowering was observed however early $50 \%$ flowering was shown in un-fertilized plots. The interaction between tillage and potassium was significant. Shallow tillage produce early flowering with the all level of potassium application which is 108 days and delay in flowering was shown in those sup plots where $80 \mathrm{~kg} \mathrm{ha}^{-1}$ of potassium was applied with the deep tillage practice which is 112 days to $50 \%$ flowering. Similar consequences were reported by that more days to anthesis were required with the application of various amounts of potassium and nitrogen. This effect on anthesis may be attributed to uninterrupted cell division and multiplication because sufficient amount of nitrogen and potassium was available which increased the time period required for completion of vegetative stage. Other factors include greater leaf area which in turn resulted in increase harvesting of light and due to these synergistic effects, vegetative growth was prolonged [28]. 
Data representing days to maturity was significantly affected by tillage practices and potassium levels which are shown in (Table 1). Delayed days to maturity was observed in those main plots where deep tillage practice was done (196.5 days), however medium deep and shallow tillage practice taken less days to maturity but they are non-significant among selves. Data of mean values exhibited that those subplots where $80 \mathrm{~kg} \mathrm{ha}^{-1}$ potassium rate was applied delayed days to maturity as compared to all those plots where less potassium was applied while early days to maturity was shown in control plots. The interaction between tillage practices and potassium levels ( $\mathrm{T} \times \mathrm{K}$ ) was also nonsignificant. The findings are in line with [29]. Delayed physiological maturity appreciably increased with application of various $\mathrm{N}$ levels due to extended grain filling duration as reported by [30]. Increase in $\mathrm{K}$ level significantly delayed maturity over two years probably because of enormous vegetative growth as investigated by [31]. In terms of potassium application those plots treated with high rate of potassium application observed delay in days to maturity; however those plots where low potassium was applied resulted early maturity these findings are in contrary with [32] their research shows that if potassium applied sole at sowing resulted in early maturity while if it is applied in split then it delays maturity.

Data pertaining to nodules weight are shown in the (Table 2). Analysis of variance indicated that tillage practice have significant effect on chickpea nodules weight. The effect of potassium was significant whereas interaction between tillage and potassium was non-significant. Mean values of the data showed that the weight of nodules is more in deep tillage (1.15 $\left.\mathrm{g} \mathrm{plant}^{-1}\right)$ as compared to medium deep tillage (0.96 $\left.\mathrm{g} \mathrm{plant}^{-1}\right)$ and shallow tillage $\left(0.81 \mathrm{~g}\right.$ plant $\left.^{-1}\right)$. Among different potassium levels potassium applied at the rate of $60 \mathrm{~kg} \mathrm{ha}^{-1}$ produced higher weight of nodules (1.10 g plant $\left.{ }^{-1}\right)$, which was statistically similar with the nodules weight produced with $80 \mathrm{~kg} \mathrm{ha}^{-1}$ whereas nodules weight of un-fertilized plots was significantly lower as compared to 80 and $60 \mathrm{~kg} \mathrm{ha}^{-1}$. Similar consequences was demonstrated by [33] they used four levels of potassium 50, $100,150,200 \mathrm{~kg} \mathrm{ha}^{-1}$ but they find more weight of nodules on $50 \mathrm{~kg} \mathrm{ha}{ }^{-1}$ further increase in potassium show decline in nodules weight.

Data on number of nodules of chickpea as affected by tillage practices and potassium levels are presented in (Table 2). Analysis of variance data shows that the number of nodules was higher in deep tillage practice but it is was significantly comparable to the shallow and medium tillage practice. Potassium has significant effect on number of nodules. $80 \mathrm{~kg} \mathrm{ha}^{-1}$ produces more number of nodules (15.8) which is significantly different from control plots but statistically similar with the $60 \mathrm{~kg} \mathrm{ha}^{-1}$ (15), whereas interaction between tillage and potassium was non-significant. this might be due to deep growth and distribution of roots. So when the surface area for nodules became more the quantity of nodules should also be increases. The data trend shows that higher potassium level gave more number of nodules and lower potassium level gave less number of nodules. These results were in harmony with [33] his observation shows that potassium high dose results in more number of nodules and less number of nodules in those plots where potassium was not applied. [34] conclusions was in conformity with our findings, stated that nodules was maximum on $120 \mathrm{~kg} \mathrm{ha}^{-1}$ which is at par with 100 and $80 \mathrm{~kg} \mathrm{ha}^{-1}$ but significantly different with the rest of the levels.

The data recorded on plant height are exposed in (Table 2). The statistical analysis of the data confirmed that the tillage and potassium significantly affect plant height. Taller plants were produced in deep tillage 
plots $(81.3 \mathrm{~cm})$ while shorter plants are produced in shallow tillage plots $(77.7 \mathrm{~cm})$. Taller plant height was produced on $80 \mathrm{~kg} \mathrm{ha}$ $1(81.3 \mathrm{~cm})$ whereas shorter plants were produced in control plots $(79.0 \mathrm{~cm})$. The interaction between tillage and potassium ( $\mathrm{T}$ $\mathrm{x} \mathrm{K}$ ) was found non-significant. Increases the root penetration is more and due to tillage practice weed infestation is less then it will increase number of pods plant ${ }^{-1}$ and also increase yield parameters. [35] reported that potassium dose of higher concentration shows more pods as compared to those plots where less potassium was applied and it also decreases the pods shelling percentage which also benefits the yield parameter which is number of pods plant ${ }^{-1}$, pods $\mathrm{m}^{-2}, 100$ grains weight and ultimately we get more grain yield.

The data obtained on hundred grains weight of chickpea as affected by tillage practices and potassium levels are represented in (Table 3). Analysis of the data revealed that the effect of tillage practice was nonsignificant. A heavier grains weight was produced on deep tilled practice and lighter grain weight was obtained at shallow and medium tillage practice. More 100 grains weight was recorded in plots treated with 80 $\mathrm{kg} \mathrm{ha}{ }^{-1}(25.3 \mathrm{~g})$ which was statistically similar with $60 \mathrm{~kg} \mathrm{ha}^{-1}(25.2 \mathrm{~g})$. The interaction between tillage practices and potassium levels ( $\mathrm{T}$ x K) was non-significant. Our findings are in congruence with [36] who presented that the higher level of potassium improved the 1000 grains weight of wheat. This increasing 1000 grains weight was also reported by [37] presented that potassium application produced significantly higher grain weight than control, 50 and $75 \mathrm{~kg} \mathrm{ha}^{-1}$ potassium produced statistically at par but had more grain weight than rest of the treatments.

The data in relation to number of grains pods

${ }^{1}$ displayed that the tillage and potassium was affected non- significantly which is shown in
(Table 2). The statistical analysis of data exposed that tillage has non-significant effect on grains pod $^{-1}$. The effect of potassium was also non-significant. The interactive effect between tillage and potassium ( $\mathrm{T} \times \mathrm{K}$ ) was also non-significant. Photosynthesis occurs in the pods of a number of legume species and result in the fixation of carbon dioxide that is present in the surrounding atmosphere of the plant and also helps in providing photo assimilates for seed development [38, 39]. The pods of chickpea (Cicer arietinum L.), are also green and they possess stomata as well so it is most probable that photosynthesis can occurs in the pods of chickpea as well.

The data relating to number of pods plant ${ }^{-1}$ of chickpea as influenced by tillage practices and levels of potassium are presented in (Table 2). Analysis of variance showed that effect of tillage practice was non-significant. Data of mean values showed that pods plant ${ }^{-}$ 1 was affected significantly by potassium application. More pods per plant were obtained at $80 \mathrm{~kg} \mathrm{ha}^{-1}$ which is at par with 60 $\mathrm{kg} \mathrm{ha}^{-1}$ (33.5) and lower pods plant ${ }^{-1}$ was observed in those plots where potassium was not applied, whereas the interaction between tillage and potassium ( $\mathrm{T} \times \mathrm{K})$ was nonsignificant.

The data regarding number of pods $\mathrm{m}^{-2}$ of chickpea as influenced by tillage practices and levels of potassium are presented in (Table 3). Statistical analysis depicted that effect of tillage practices was non-significant. Data of mean values indicated that pods $\mathrm{m}^{-2}$ was affected significantly by potassium application. Higher number of pods $\mathrm{m}^{-2}$ were obtained at $80 \mathrm{~kg} \mathrm{ha}^{-1}\left(837.5 \mathrm{~m}^{-2}\right)$ followed by $60 \mathrm{~kg} \mathrm{ha}^{-1}\left(836.6 \mathrm{~m}^{-2}\right)$ and lower pods ${ }^{-2}$ was found in un-fertilized plots $\left(751 \mathrm{~m}^{-2}\right)$, whereas the interaction between tillage and potassium levels ( $\mathrm{T}$ x K ) was obtained nonsignificant.

Biological yield of chickpea was significantly affected by different tillage 
practices $(\mathrm{T})$ and potassium levels $(\mathrm{K})$ (Table 3). The interaction between tillage and potassium ( $\mathrm{T} \times \mathrm{K}$ ) was found non-significant. Mean values of the data revealed that deep tillage produced higher yield, (4155 kg ha-1) as compared to medium deep and shallow tillage (4054 $\left.\mathrm{kg} \mathrm{ha}^{-1}\right)$ and (3070 $\left.\mathrm{kg} \mathrm{ha}^{-1}\right)$. Among different potassium levels potassium applied at the rate of $80 \mathrm{~kg} \mathrm{ha}^{-1}$ produced higher biological yield (4244 $\left.\mathrm{kg} \mathrm{ha}^{-1}\right)$, which was statistically similar with biological yield produced with $60 \mathrm{~kg} \mathrm{~K} \mathrm{ha}^{-1}$ (4197 $\mathrm{kg} \mathrm{ha}^{-1}$ ) The biological yield was lower in control plots where no potassium was applied. Potassium is the most abundant inorganic action in plants and contributes to about $10 \%$ of the dry plant mass [40-43] stated that biological yield had positive relationship with plant height, number of branches, number of pods per plant and 100 seed weight.

Data relating grain yield are presented in (Table 3). Data revealed that there was significant effect of tillage practices and potassium levels on grain yield. More grain yield was obtained at deep tillage practice (1447 kg ha-1) followed by medium deep tillage (1382 $\mathrm{kg} \mathrm{ha}^{-1}$ ), whereas lower grain yield was depicted at shallow deep tillage (1383 kg ha $\left.{ }^{-1}\right)$. Higher grain yield was obtained for $80 \mathrm{~kg} \mathrm{ha}$ application of potassium $\left(1483 \mathrm{~kg} \mathrm{ha}^{-1}\right)$ followed by $60 \mathrm{~kg}$ $\mathrm{ha}^{-1}$ application (1468 $\mathrm{kg} \mathrm{ha}^{-1}$ ) whereas lower grain yield (1257 kg ha-1) was obtained in those plots where potassium was not applied. The interactive effect of tillage and potassium was non-significant. Chickpea grain yield is a quantitative character, affected by genetic factors, environmental fluctuations and cultural practices like ploughing [44]. Grain yield is more in potassium fertilized plots. However, it might be due to optimum potassium which have synergistic effect with nitrogen and this nitrogen is obtained from nitrogen fixation of nodules which makes nitrogen adequate for proper functioning and sooner or later it increases the grain yield. These results are in accordance with [45-48]. Our remarks are in harmony with [49] whose report shows that potassium has important role in water use efficiency and enhances plant growth condition and cell division and also results in quick transportation of photoassimilates towards sink which is grain yield. Potassium might have increased the rate of $\mathrm{CO}^{2}$ assimilation, stabilized the osmosis regulation, improved stomata closure and enzyme activity as a result of which more carbohydrates might have produced which might have increased grain yield as observed by [50]. [51] Conclusions are in close agreement with our reports that foliar application of potassium increased grain yield. Same interpretation was observed from the findings of [52].

Data on the topic of harvest index are presented in (Table 3). Data indicated that tillage practices significantly affected harvest index. Data of mean value exhibited that potassium levels non-significantly affect harvest index. Higher harvest index was observed in deep tillage $(37.5 \%)$ which was statistically significant from medium deep tillage $(36.8 \%)$ and lower harvest index was recorded at shallow tillage (36.4\%). Higher harvest index $(37.6 \%)$ was obtained for 60 $\mathrm{kg} \mathrm{ha}^{-1}$, followed by $80 \mathrm{~kg} \mathrm{ha}^{-1}$ application (37.6), while lower harvest index was obtained in control plots $(36 \%)$. The interactive effect of tillage practices and potassium levels ( $\mathrm{T} \times \mathrm{K}$ ) was found nonsignificant. 
Table 1. Days to emergence, Emergence $\mathrm{m}^{2}$, Weeds density $\left(\mathrm{m}^{2}\right)$, No of branches plant ${ }^{1}$, Days to $50 \%$ flowering and Days to maturity as affected by different tillage practices and potassium levels

\begin{tabular}{|c|c|c|c|c|c|c|}
\hline $\begin{array}{c}\text { Potassium } \\
\left(\mathrm{kg} \mathrm{ha}^{-1}\right)\end{array}$ & $\begin{array}{c}\text { Days to } \\
\text { Emergence }\end{array}$ & $\begin{array}{c}\text { Emergen } \\
{\text { ce } \mathbf{~ m}^{2}}\end{array}$ & $\begin{array}{c}\text { Weeds } \\
\text { density }\left(\mathbf{m}^{-2}\right)\end{array}$ & $\begin{array}{c}\text { branches } \\
\text { plant }^{-1}\end{array}$ & $\begin{array}{c}\text { Days to } 50 \% \\
\text { flowering }\end{array}$ & $\begin{array}{c}\text { Days to } \\
\text { maturity }\end{array}$ \\
\hline 0 & 15.2 & 46.4 & 468 & $9.7 \mathrm{~b}$ & 109.3 & $195.3 \mathrm{~b}$ \\
\hline 20 & 14.2 & 46.2 & 471 & $10.0 \mathrm{ab}$ & 109.2 & $195.4 \mathrm{~b}$ \\
\hline 40 & 14.1 & 48.3 & 476 & $10.4 \mathrm{ab}$ & 109.2 & $195.4 \mathrm{ab}$ \\
\hline 60 & 14.5 & 48.4 & 477 & $10.7 \mathrm{ab}$ & 109.2 & $195.4 \mathrm{~b}$ \\
\hline 80 & 13.3 & 48.6 & 499 & $11.0 \mathrm{a}$ & 109.5 & $196.8 \mathrm{a}$ \\
\hline \multicolumn{7}{|l|}{ Tillage } \\
\hline Shallow & 14.1 & 47.4 & $502 \mathrm{~b}$ & 9.8 & 108.9 & $195.3 \mathrm{~b}$ \\
\hline $\begin{array}{l}\text { Medium } \\
\text { Deep }\end{array}$ & 14.5 & 47.3 & $491 \mathrm{a}$ & 10.2 & 109.2 & $195.2 \mathrm{~b}$ \\
\hline Deep & 14.2 & 48 & $443 \mathrm{a}$ & 11 & 109.8 & $196.5 \mathrm{a}$ \\
\hline \multicolumn{7}{|l|}{ LSD (0.05) } \\
\hline Tillage (T) & $\mathrm{ns}$ & $\mathrm{ns}$ & 29.8 & 0.62 & Ns & 0.98 \\
\hline $\begin{array}{l}\text { Potassium } \\
\text { (K) }\end{array}$ & ns & ns & $\mathrm{ns}$ & ns & Ns & 1.1 \\
\hline $\mathbf{T} \times \mathbf{K}$ & $\mathrm{ns}$ & $\mathrm{ns}$ & ns & ns & Ns & ns \\
\hline
\end{tabular}

Table 2. Nodules weight (g plant $\left.{ }^{-1}\right)$, Number of nodules plant ${ }^{-1}$, Plant height $(\mathrm{cm})$, Number of grains pod $^{-1}$, Pods plant ${ }^{-1}$ as affected by different tillage practices and potassium levels

\begin{tabular}{|c|c|c|c|c|c|}
\hline $\begin{array}{c}\text { Potassium } \\
\left(\mathrm{kg} \mathrm{ha}^{-1}\right)\end{array}$ & $\begin{array}{l}\text { Nodules weight } \\
\left(\mathrm{g}_{\text {plant }}{ }^{-1}\right)\end{array}$ & $\begin{array}{c}\begin{array}{c}\text { Number of } \\
\text { nodules plant }\end{array} \\
\text { nod }\end{array}$ & $\begin{array}{c}\text { Plant } \\
\text { height }(\mathrm{cm})\end{array}$ & $\begin{array}{l}\text { Number of } \\
\text { grains pod }^{-1}\end{array}$ & $\begin{array}{c}\text { Pods } \\
\text { plant }^{-1}\end{array}$ \\
\hline 0 & $0.82 \mathrm{~b}$ & $13.8 \mathrm{~b}$ & $79.0 \mathrm{c}$ & 1.8 & $30.1 \mathrm{~b}$ \\
\hline 20 & $0.92 \mathrm{ab}$ & $14.1 \mathrm{~b}$ & $80.0 \mathrm{~b}$ & 1.8 & $29.6 \mathrm{~b}$ \\
\hline 40 & $0.96 \mathrm{ab}$ & $14.7 \mathrm{~b}$ & $80.4 \mathrm{ab}$ & 1.9 & $32.6 \mathrm{ab}$ \\
\hline 60 & $1.10 \mathrm{a}$ & $15.0 \mathrm{ab}$ & $80.5 \mathrm{ab}$ & 1.7 & $33.5 \mathrm{a}$ \\
\hline 80 & $1.07 \mathrm{a}$ & $15.8 \mathrm{a}$ & $81.3 \mathrm{a}$ & 1.7 & $33.5 \mathrm{a}$ \\
\hline \multicolumn{6}{|l|}{ Tillage } \\
\hline Shallow & $0.81 \mathrm{~b}$ & 14.7 & $77.7 \mathrm{c}$ & 1.8 & 31.2 \\
\hline $\begin{array}{c}\text { Medium } \\
\text { Deep }\end{array}$ & $0.96 \mathrm{~b}$ & 14.7 & $79.7 \mathrm{~b}$ & 1.7 & 32.2 \\
\hline Deep & $1.15 \mathrm{a}$ & 14.7 & $83.3 \mathrm{a}$ & 1.9 & 32.1 \\
\hline \multicolumn{6}{|l|}{ LSD (0.05) } \\
\hline Tillage (T) & 0.16 & $\mathrm{~ns}$ & 1.06 & ns & ns \\
\hline $\begin{array}{l}\text { Potassium } \\
\text { (K) }\end{array}$ & 0.2 & 1.2 & 1 & ns & 3 \\
\hline $\mathbf{T} \times \mathbf{K}$ & $\mathrm{ns}$ & ns & ns & ns & ns \\
\hline
\end{tabular}


Table 3. 100 grains weight (g), Pods $\mathrm{m}^{-2}$, Biological yield $\left(\mathrm{kg} \mathrm{ha}^{-1}\right)$, Grain yield (kg ha-1) and Harvest index (\%) as affected by different tillage practices and potassium levels

\begin{tabular}{|c|c|c|c|c|c|}
\hline $\begin{array}{c}\text { Potassium (kg } \\
\left.\text { ha }^{-1}\right)\end{array}$ & $\begin{array}{l}100 \text { grains } \\
\text { weight }(\mathrm{g})\end{array}$ & Pods $\mathrm{m}^{-2}$ & $\begin{array}{c}\text { Biological yield } \\
\left(\mathrm{kg} \mathrm{ha}^{-1}\right)\end{array}$ & $\begin{array}{c}\text { Grain yield (kg } \\
\left.\text { ha }^{-1}\right)\end{array}$ & $\begin{array}{c}\text { Harvest } \\
\text { index }(\%)\end{array}$ \\
\hline 0 & $24.3 \mathrm{c}$ & $751.3 \mathrm{~b}$ & $3797 \mathrm{c}$ & $1258 \mathrm{c}$ & $36.0 \mathrm{~b}$ \\
\hline 20 & $24.0 \mathrm{c}$ & $741.2 \mathrm{~b}$ & $3934 \mathrm{~b}$ & $1340 \mathrm{~b}$ & $36.9 \mathrm{ab}$ \\
\hline 40 & $24.4 \mathrm{bc}$ & $814.3 \mathrm{ab}$ & $4127 \mathrm{a}$ & $1395 \mathrm{~b}$ & $36.5 \mathrm{~b}$ \\
\hline 60 & $25.2 \mathrm{ab}$ & $836.6 \mathrm{a}$ & $4197 \mathrm{a}$ & $1468 \mathrm{a}$ & $37.6 \mathrm{a}$ \\
\hline 80 & $25.3 \mathrm{a}$ & $837.5 \mathrm{a}$ & $4244 \mathrm{a}$ & $1483 \mathrm{a}$ & $37.6 \mathrm{a}$ \\
\hline \multicolumn{6}{|l|}{ Tillage } \\
\hline Shallow & 24.5 & 780.9 & $3970 \mathrm{c}$ & $1336 \mathrm{c}$ & $36.4 \mathrm{c}$ \\
\hline Medium Deep & 24.7 & 805.8 & $4054 \mathrm{~b}$ & $1383 \mathrm{~b}$ & $36.8 \mathrm{~b}$ \\
\hline Deep & 24.8 & 801.8 & $4155 \mathrm{a}$ & $1447 \mathrm{a}$ & $37.5 \mathrm{a}$ \\
\hline \multicolumn{6}{|l|}{ LSD (0.05) } \\
\hline Tillage (T) & $\mathrm{ns}$ & ns & 62 & 20.8 & 0.4 \\
\hline Potassium (K) & 0.8 & 73.9 & 136 & 58 & 1 \\
\hline T $x$ K & $\mathrm{ns}$ & $\mathrm{ns}$ & $\mathrm{ns}$ & ns & ns \\
\hline
\end{tabular}

\section{Conclusion and recommendations}

It was concluded from the upper results of the experiment; among tillage practices, deep tillage performed better as compared with shallow and medium deep tillage practices in terms of yield and yield components, potassium application at the rate of 60 and 80 $\mathrm{kg} \mathrm{ha}{ }^{-1}$ improved growth and productivity. On the basis of the above conclusions, it is recommended that deep tillage practice and Potassium at the rate of $60 \mathrm{~kg} \mathrm{ha}^{-1}$ is recommended for productivity of chickpea in Peshawar.

\section{Authors' contributions}

Conceived and designed the experiments: A Ahmad \& Inamullah, Performed the experiments: A Ahmad, Analyzed the data: A Ahmad, H Nawaz \& MM Anjum, Contributed materials/ analysis/ tools: $\mathrm{H}$ Nawaz, N Ali \& M Zuhair, Wrote the paper: H Nawaz, A Ahmad, M Kefayatullah, MFK Pasha, M Shah, Y Jan \& M Khan.

\section{References}

1. Smithson J B, J A Thompson \& RJ Summerfield (1985). Chickpea (Cicer arietinum L.). In: R.J. Summerfield and E.H. Roberts (eds.), Grain Legume Crops. Collins, London, UK p 312-390.
2. Singh F \& B Diwakar (1995). Chickpea botany and production practices. Skill Development Series. 16: 8-9.

3. Nelson CJ, Zarrough KM. Tiller density and tiller weight as yield determinants of vegetative swards. Plant physiology and herbage production. Hurley: British Grassland Society. 1981:25-9.

4. Akram M (2013). Effect of potassium nutrition on solute accumulation, ion composition and yield of maize hybrids grown under saline conditions. J. Plant Nutr 36(1): 143-163.

5. Kumar S \& S K Trivedi (2005). Response of chickpea to phosphorus and bio-fertilizers. Legume Res 28(1): 58-61.

6. Meena LR, RK Singh \& RC Gautam (2003). Yield and nutrient uptake of chickpea as influenced by phosphorus levels. Legume Res 26(2): 109-112.

7. Saeed M, HM Akram, MS Iqbal, A Yar \& A Ali (2004). Impact of fertilizer on the seed yield of chickpea. Int J Agric Biol 6(1): 108109.

8. Sharar MS, M Ayub, MA Chaudhry \& M Nadeem (2000). Effect of NP application and inoculation on the growth and yield of gram. Pak J Agri Sci 37(3-4): 155-157.

9. Nabham H, CAD Bie \& MT Saleem (1989). Potassium and fertilizer use efficiency NDFC, Planning and Development 
Division. Govt of Pakistan. Islamabad. 4169.

10. Rice CW \& MS Smith (1982). Denitrification in no-till and plowed soils. Soil Sci. Soc. American Proc 46: 1168 1173.

11. McKenny D J, S W Wang, C F Drury \& W I Findlay (1993). Denitrification and mineralization in soil amended with legume, grass and corn crop residues. Soil Sci Soc American J 57: 1013-1020.

12. Khurshid K, M Iqbal, M S Arif \& A Nawaz (2006). Effect of tillage and mulch on soil physical properties and growth of maize. Int J Agric Biol 8: 593-596.

13. Fan M X, A F MacKenzie, M Abbott \& F Cadrin (1997). Denitrification estimates in monoculture and rotation corn as influence by tillage and nitrogen fertilizer. Can J Soil Sci 77: 389-396.

14. Unger PW, BA Stewart, JF Parr \& RP Singh (1991). Crop residue management and tillage methods for conserving soil and water in semi-arid regions. Soil Till Res 20: 219240.

15. Zorita M D (2000). Effect of deep tillage and nitrogen fertilization interactions on dry land corn productivity. Soil Till Res 54: 11-19.

16. Patil S L \& M N Sheelavantar (2006). Soil water conservation and yield of winter sorghum as influenced by tillage, organic materials and nitrogen fertilizer in semi-arid tropical India. Soil till Res 89: 246-257.

17. Kepner R A, R Bainer \& E Barger (1982). Principle of farm machinery, $3^{\text {rd }}$ Ed. AVI Publishing, Inc west post Connectient USA.

18. Jan M, P Shah, P A Hoolinton, M J Khan \& Q Sohail (2009). Agriculture research Design and Analysis Deptt Of Agronomy KP Agric Uni Peshawar Pakistan.

19. Singh K, A K Mishra, B Singh, R P Singh, D D Patra (2014). Tillage effects on crop yield and physicochemical properties of Sodic soils. Land degradation \& development. 27(2): 132140.

20. Sadiq M, G Hassan, SM Mehdi, N Hussain \& M Jamil (2007). Amelioration of salinesodic soils with tillage implements and sulfuric acid application. Pedosphere 17: 182-190.
21. Sime-Ngando T (2014). Environmental bacteriophages: viruses of microbes in aquatic ecosystems. Frontiers in microbiology 24;5:355.

22. Sime G, Aune JB \& Mohammed H (2015). Agronomic and economic response of tillage and water conservation management in maize, central rift valley in Ethiopia. Soil and Tillage Res 1(148): 20-30.

23. Clements DR, DL Benoit, SD Murphy \& CJ Swanton (1996). Tillage effects on weed seed return and seed bank composition. Weed Sci 44: 314-332.

24. Swanton CJ, A Shrestha, SZ Knezevic, RC Roy \& BR Ball Coelho (2000). Influence of tillage type on vertical weed seed bank distribution in a sandy soil. Can J Plant Sci 80: 455-457.

25. Roberts H A \& Dawkins P A (1967). Effect of cultivation on the numbers of viable weed seeds in soils. Weed Res 7:290-301.

26. Wright S D \& Vargas R N (2003). Integrating weed management tools in cotton and corn: GMO's and conventional herbicides. In Proc Calif Weed Sci Soc 55: 117-122.

27. Ayyoub M (1985). Effect of NPK fertilizer application on the yield and quality of mungbean (Viglla radiata). M.Sc. Thesis, Dept. Agron Univ Agri Faisalabad.

28. Delden \& V Arnout (2001). Yield and growth components of potato and wheat under organic nitrogen management. Agronomy Journal 93(6): 1370-1385.

29. Frederick JR \& JJ Camberato (1995). Water and nitrogen effects on winter wheat in the southeastern coastal plain: II. Physiological response. Agron J 87: 527-532.

30. Ayub M, S Guertin, S Lussier \& DL Smith (1994). Timing and level of nitrogen effects on spring wheat yield in eastern Canada. Crop Sci 34(3): 748-756.

31. Seilsepour M (2007). Study of wheat grain protein increasing through foliar application of nitrogen after anthesis. Biaban J 12: 1-5.

32. Asif M, Amanullah \& M Anwar (2007). Phenology, Leaf Area and Yield of Spring Maize (Cv. Azam) as Affected by Levels and Timings of Potassium Application. World Appl Sci J 2(4): 299-303. 
33. Boulbaba L, S Bouazi, TA Mainassara, L Zourgvi \& L Mokhtar (2005). Response of chickpea (Cicer arietinum L.) to potassium fertilization. $J$ Agric and Social Sci 1: 7—9.

34. Kurdali F, F Al-Ain \& M Al-Shamma (2002). Nodulation, dry matter production, and N2 fixation by fababean and chickpea as affected by soil moisture and potassium fertilizer. J plant nut 25(2): 355-368.

35. Moinuddin \& P Imas (2014). Potassium uptake in relation to drought tolerance of chickpea under rain-fed conditions. J Plant Nutri 37(7): 1120-1138.

36. Ijaz U (2004). Response of rice and wheat crops to potassium fertilization in saline sodic soils. M.Sc (Hons) thesis, Deptt. of Soil Science Univ of Agric Faisalabad Pakistan.

37. Asghar AU, M A Mauk, R A Abid, M Tahir \& H Arif (1994). Effect of potassium on yield and yield Components of black gram. Pak J Agri Sci 31(3): 275-278.

38. Quebedeauz B \& R Chollet (1975). Growth and development of soyabean (Glycine max L. Merr.) pods. $\mathrm{CO} 2$ exchange and enzyme studies. Plant Physiol 55: 745-748.

39. Pate J S, PJ Sharkey \& CA Atkins (1977). Nutrition of a developing legume fruit. Plant Physiol 59: 506-510.

40. Chand H, IS Srivastava \& RB Trehan (1975). Estimates of genetic parameters, correlation coefficient and path coefficient analysis in gram (Cicer arietinum L.). Madras Agri J 62: 178-181.

41. Katiyar RP, J Prased, RB Sigh \& K Ram (1977). Association analysis of grain yield and its components in segregation population of chickpea. Plant Breed. Abst. Ind J Agric Sci 48: 4965.

42. İslam MO \& B Begüm (1985). Stability of chickpea variety for sowing date in Bangladesh. Ins J Agri Sci 55: 228-232.

43. Khan IA, M Bashir \& BA Malik (1989). Character association and their implication in chickpea breeding. Pak J Agri Sci 26: 214220.

44. Muehlbauer FJ \& KB Singh (1987). Genetics of chickpea. In: The Chickpea. (Eds.): M.C. Saxena and K.B. Singh, CAB International Pub Wallingford pp. 99-125.

45. Sharma MP \& JP Gupta (1998). Effect of organic materials on grain yield and soil properties in maize wheat cropping systems. Ind J Agric Sci 68: 715-717.

46. Maqsood M, AM Abid, A Iqbal \& M I Hussain (2001). Effect of variable rate of nitrogen and phosphorus on growth and yield of maize (golden). J Bio Sci 1: 19-20.

47. Sharar MS, M Ayub, MA Nadeem \& N Ahmad (2003). Effect of different rates of nitrogen and phosphorus on growth and grain yield of maize. Pak J Agri Sci 35: 134140

48. Asghar A, A Ali, W H Syed, M Asif, T Khaliq \& A A Abid (2010). Growth and yield of maize cultivars affected by NPK application in different proportion. Pak J Sci 62(4): 211-216.

49. Marschner H (1995). Mineral nutrition of higher plants. $2^{\text {nd }}$ ed. Academic Press, San Diego, NY. Ca. pp: 379-396.

50. Ebrahimi ST, M Yarnia, MK Benam \& EFM Tabrizi (2011). Effect of potassium fertilizer on corn yield (Jeta cv.) under drought stress condition. American-Eurasian Journal Agriculture and Environ Sci 10(2): 257-263.

51. Narang RS, SS Mahal, B Seema, KS Gosal \& S Bedi (1997). Response of rice and wheat of K-fertilization under maximum yield research strategies. Enviro Eco 19(2): 474477.

52. Ahmad MK, MS Khan \& MI Makhdum (1990). Influence of different tillage implements on wheat production in barani areas of the Punjab. Sarhad J Agric 6(2): 179-184. 